\title{
A Study on Customers Attitude towards the Problems of Internet Banking Services in Madurai City
}

\section{OPEN ACCESS}

Manuscript ID:

COM-2021-09013503

Volume: 9

Issue: 1

Month: January

Year: 2021

E-ISSN: 2582-6190

Received: 19.10 .2020

Accepted: 07.12.2020

Published: 01.01.2021

Citation:

Andy, R., and A. Sujatha.

"A Study on Customers

Attitude towards the

Problems of Internet

Banking Services in

Madurai City." ComFin

Research, vol. 9, no. 1,

2021, pp. 17-21.

DOI:

https://doi.org/10.34293/

commerce.v9i1.3503

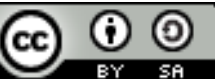

This work is licensed under a Creative Commons

Attribution-ShareAlike 4.0 International License
R. Andy

Assistant Professor (Research Scholar), Department of Commerce

Pasumpon Muthuramalinga Thevar College, Usilampatti, Madurai, Tamil Nadu, India

\author{
A. Sujatha \\ Assistant Professor, Department of Commerce \\ Cardomon Plant Associations College, Bodinayakannur, Theni, Tamil Nadu, India
}

\begin{abstract}
The banking industry has been developing by using Internet banking as a well-organized and practicable tool to create customer value. In the banking sector, different electronic delivery channels are increasingly used for delivering banking products and services that convenient for the customers at a low cost. Internet Banking (IB) is one among them in the banking sector. It is one of the smart services offered by traditional banks to offer speed and reliable services to online users. With the fast development of computer-based technology, the Internet Banking can draw more customers to perform banking dealings in related banks. However, the main issue of Internet banking faced by bankers is that a large number of banking customers are not ready to use the Internet banking services offered by banks. This happens due to the services offered through Internet banking is yet to encourage its customers. Customer satisfaction is an important factor that helps the banks to maintain competitive advantages. Therefore, this study is to observe the factors that influence the customers' satisfaction towards Internet banking. The study concentrates on the following factors that can influence customers' satisfaction toward Internet banking, which include services, web design, security, and convenience. The sample size taken for the study was 100 respondents who provided valuable feedback to pertain to the above factors that influence customers' decision to use Internet Banking.
\end{abstract}

Keywords: Internet banking, Banking industry, Customer Satisfaction, Security services, Banking services, Online banking.

\section{Introduction}

The financial reforms that were initiated within the early 1990s and therefore the globalization and liberalization measures brought a completely new opening environment to the banks. The bankers are now offering modern and smart technology-based services and products like 'Anywhere Anytime Banking', 'Tele-Banking', 'Internet Banking', and 'Web Banking' etc., to their customers.

Internet Banking in India is currently at a growing stage. While there are many companies specializing in primary Internet banking software, security software, and internet sites; thus, in India, slowly but steadily, the Indian customer is moving in the direction of Internet banking. A variety of banks has either adopted. Internet banking is on the smart of adopting it. The banks started Internet banking initially with a simple task like getting information about interest rates, checking account balances and computing loan eligibility. Then, the services are extended to online bill payment, transfer of funds between accounts and cash managing services for corporate. Recently, banks need to make easy payments of e-commerce dealings by directly debiting bank accounts or through credit cards. 


\section{Review of Literature}

Sunith (2019) study has attempted to mark out the extent of satisfaction of E-Banking customers. Hypothesis tests expose that respondents are satisfied with the competency and efficiency of E-Banking services. Respondents are satisfied with the accuracy and consequence of information provided by the banks and the management of web portals for E-Banking services. Hypothesis tests helped identify some of the vulnerabilities that banks need to focus upon and improve to enhance customer satisfaction, build a customer base and strengthen their loyalty. Again, it is said that retaining existing customers is easier than finding new customers.

Pratima Merugu and Krishna Mohan Vaddadi (2018) study primarily focuses on exploring the factors that influence online customers' satisfaction with references to the overall service quality of their banks. The study not also helps in assessing the significance of these factors in the context of Online (Internet) banking but also to strengthen the bond between the banks and the customers, thereby serving them to retain and expand their overall customer base. First, the study identified website design, service reliability, customer service, communication and security are the major determinants of customer satisfaction concerning online / Internet banking.

Santhiya Ran and Saravanan (2018) study reveals to evaluate and examine the level of satisfaction towards internet banking services. This research will support bank organizational to ascertain a better understanding of customers' satisfaction towards internet banking offered by the general bank customers in Coimbatore city. Basic supposition only those customers who know how to use the Internet and have access to the Internet. The study considered only the situation wherein banks provide Internet banking services. By grouping, the variable less than one relevant question may result in proper implication for the bankers.

\section{Statement of the Problem}

Advent and implementation of the internet by the industries have removed time, distance and communication, making the world truly a small village. The financial sector is no exception. Various features such as competitive cost, customer service, increase in education and income level of customers, and the banks like to evaluate their technology and assess their e-commerce and internet banking strategies. Internet banking allows banking from anywhere, anytime and is used for dealing with banks over the internet. In Internet Banking, a client has one-to-one dealings with the bank's website, and in such a situation, it is important on the part of the bank to provide high-quality services over the internet. Customer satisfaction, customer maintenance and new customer acquisition are the key issues in the internet banking system. Internet banking now is more of a norm rather than exclusion in many developed countries due to the reality that it is the cheapest way of providing banking services. This paper examines the consequence of internet banking on banks' performance management in Madurai city. It also seeks to examine customer's perception of the services provided by the banks interrelated and revolutionized by the internet.

\section{Objectives of the Study}

- To expose socio-economic profile of respondents.

- To measure the level of satisfaction of the respondents towards Internet Banking services.

- To reveal the issues faced by the respondents.

\section{Hypothesis}

- There is no association between the gender and satisfaction level of the respondents.

- There is no association between the income and satisfaction level of the respondents.

\section{Methodology}

Source of Data: This study is based on primary data. The data has been collected directly from the customers of banks by using a questionnaire prepared exclusively for this study.

Sample Design: The 120 samples were selected from the total population for this study. A convenient method of sampling technique is applied to get the questionnaire.

Tools for Analysis: The collected data were processed further with the help of the SPSS to analyze and interpret the data in the study. The Chisquare test is used to determine the significance of the relationship between the variables. 
Analysis and Interpretation

Table 1: Demographic Profile of the Respondents

\begin{tabular}{|c|c|c|c|c|}
\hline $\begin{array}{l}\text { S. } \\
\text { No }\end{array}$ & \multicolumn{2}{|c|}{ Demographic } & Frequency & $\%$ \\
\hline \multirow{3}{*}{1} & \multirow{3}{*}{ Gender } & Male & 65 & 65 \\
\hline & & Female & 35 & 35 \\
\hline & & Total & 100 & 100 \\
\hline \multirow{5}{*}{2} & \multirow{5}{*}{ Age } & Less than 25 & 27 & 27 \\
\hline & & $25-35$ & 50 & 50 \\
\hline & & $35-45$ & 18 & 18 \\
\hline & & More than 45 & 5 & 5 \\
\hline & & Total & 100 & 100 \\
\hline \multirow{3}{*}{3} & \multirow{3}{*}{$\begin{array}{l}\text { Marital } \\
\text { Status }\end{array}$} & Married & 40 & 40 \\
\hline & & Unmarried & 60 & 60 \\
\hline & & Total & 100 & 100 \\
\hline \multirow{4}{*}{4} & \multirow{4}{*}{$\begin{array}{l}\text { Education } \\
\text { Qualification }\end{array}$} & School level & 11 & 11 \\
\hline & & Graduation & 30 & 30 \\
\hline & & PG & 59 & 59 \\
\hline & & Total & 100 & 100 \\
\hline \multirow{6}{*}{5} & \multirow{6}{*}{$\begin{array}{l}\text { Employment } \\
\text { Status }\end{array}$} & Business & 11 & 11 \\
\hline & & Employed & 36 & 36 \\
\hline & & Professionals & 26 & 26 \\
\hline & & Students & 21 & 21 \\
\hline & & Others & 6 & 6 \\
\hline & & Total & 100 & 100 \\
\hline \multirow{5}{*}{6} & \multirow{5}{*}{ Income } & $<20000$ & 8 & 8 \\
\hline & & $20000-30000$ & 50 & 50 \\
\hline & & $30000-40000$ & 35 & 35 \\
\hline & & $>40000$ & 7 & 7 \\
\hline & & Total & 100 & 100 \\
\hline
\end{tabular}

Source: Primary Data
From Table 1, the sample customers are mostly 50 percent in the age group of 25-35. It is also evident from the table that 27 percent are youngsters was below 25 years, 18 percent are between 35 and 45 years, and 5 percent are above 45 years. In the gender category, 65 percent were male and 35 percent were female respondents. Furthermore, the maximum of respondents is unmarried of 60 percent and 40 percent married. The respondents' education levels are 59 percent of post-graduates, 30 percent of graduates and 11 percent of school level. About occupational status, 21 percent of the respondents' are students, 11 percent of Business men, 36 percent of the private employee, 26 percent of professionals, and 6 percent. From the table, the majority of respondents' are in employment level with 36 percentages. The income levels of the respondents are between Rs. 20,000 and Rs. 30,000 were 50 percent, income less than Rs. 20,000 were off 8 percent of and more than Rs. 40,000 income was 7 percent.

\section{Chi-Square Analysis}

The chi-square test was used to test whether the personal independent variables of the respondents have significant influences over the satisfaction level. Considered the personal characteristics of the respondents considered were: Gender and Income.

Table 2 shows that the calculated value of chi-square is less than the table value. So the null hypothesis is accepted and concluded that there is no significant difference between gender and the level of satisfaction of respondents towards the services provided by Internet banking.

Table 2: Relationship between Gender and Level of Satisfaction of the Respondents

\begin{tabular}{|c|c|c|c|c|c|c|c|c|c|}
\hline \multirow{2}{*}{$\begin{array}{l}\text { S. } \\
\text { No }\end{array}$} & \multirow{2}{*}{ Gender } & \multicolumn{3}{|c|}{ Level of Satisfaction } & \multirow{2}{*}{ Total } & \multirow{2}{*}{$\begin{array}{l}\text { Degrees of } \\
\text { freedom }\end{array}$} & \multirow{2}{*}{$\begin{array}{c}\text { Level of } \\
\text { significance }\end{array}$} & \multirow{2}{*}{$\begin{array}{c}\text { Calculated } \\
\text { value }\end{array}$} & \multirow{2}{*}{$\begin{array}{l}\text { Table } \\
\text { value }\end{array}$} \\
\hline & & Low & Medium & High & & & & & \\
\hline 1 & Male & 06 & 40 & 19 & 65 & \multirow{3}{*}{2} & \multirow{3}{*}{0.05} & \multirow{3}{*}{0.971} & \multirow{3}{*}{5.099} \\
\hline 2 & Female & 04 & 25 & 06 & 35 & & & & \\
\hline \multicolumn{2}{|c|}{ Total } & 10 & 65 & 25 & 100 & & & & \\
\hline
\end{tabular}

Source: Primary Data

Table 3 shows that the calculated value of chi-square is less than the table value. So the null hypothesis is accepted and concluded that there is no significant difference between income and the level of satisfaction of respondents towards the services provided by Internet banking. 
Table 3: Relationship Between Income and Level of Satisfaction of the Respondents

\begin{tabular}{|c|c|c|c|c|c|c|c|c|c|}
\hline \multirow{2}{*}{ S. No } & \multirow{2}{*}{ Income } & \multicolumn{3}{|c|}{ Level of satisfaction } & \multirow{2}{*}{ Total } & \multirow{2}{*}{$\begin{array}{l}\text { Degrees of } \\
\text { freedom }\end{array}$} & \multirow{2}{*}{$\begin{array}{c}\text { Level of } \\
\text { significance }\end{array}$} & \multirow{2}{*}{$\begin{array}{c}\text { Calculated } \\
\text { value }\end{array}$} & \multirow{2}{*}{$\begin{array}{l}\text { Table } \\
\text { value }\end{array}$} \\
\hline & & Low & Medium & High & & & & & \\
\hline 1 & Less than 20000 & 3 & 8 & 3 & 14 & \multirow{5}{*}{6} & \multirow{5}{*}{0.05} & \multirow{5}{*}{5.021} & \multirow{5}{*}{12.6} \\
\hline 2 & $20000-30000$ & 4 & 16 & 8 & 28 & & & & \\
\hline 3 & $30000-40000$ & 5 & 27 & 9 & 41 & & & & \\
\hline 4 & More than 40000 & 2 & 11 & 4 & 17 & & & & \\
\hline & Total & 14 & 62 & 24 & 100 & & & & \\
\hline
\end{tabular}

Source: Primary Data

Table 4: Ranking the Problems Faced by the Respondents

\begin{tabular}{|l|c|c|}
\hline \multicolumn{1}{|c|}{ Factors } & Mean & Rank \\
\hline Low speed & 5.20 & I \\
\hline Connection lost while processing & 5.32 & II \\
\hline Account temporarily locked by bank & 4.37 & VII \\
\hline $\begin{array}{l}\text { Transaction failed but amount is } \\
\text { deducted }\end{array}$ & 4.50 & VI \\
\hline Lengthy procedure & 4.83 & IV \\
\hline Forget password due to frequent changes & 5.00 & III \\
\hline My personal information leaked out & 4.27 & VIII \\
\hline $\begin{array}{l}\text { Poor response from bank on } \\
\text { complaints }\end{array}$ & 4.68 & V \\
\hline
\end{tabular}

Source: Primary Data

The study reveals that most of the respondents face problems while using internet banking is connection lost while processing is ranked first. The low speed problem is ranked second. Forget password and Lengthy procedure are ranked as third and fourth place.

\section{Suggestions}

- Most of the web-based difficulty such as low speed, connection lost while processing transactions, etc. may not be the reach of banks and they may not have much to solve these problems. However, for the problem of account temporarily locked by bank', the bank can make the customers aware that their account will be temporarily locked if they make multiple incorrect password entry, to ensure security. What the banks can do in this regard is to advise users to choose passwords that are easy to remember for them but difficult to be guessed by others.

- The quickness of the web site on bank's portal site loading. To increase the speed of the online system, the management would need to increase the speed or bandwidth for effective browsing and opening of pages; especially pages with video and pictures require high bandwidth.

- Prompt responses to customer requests. This relates to customer relationships. This needs training of more able customer service staff that would be able to hold customer request promptly.

- Internet banking system's ability to guide customers to resolve problems. Customer may have many troubles in accessing and utilizing online banking portals; it is the liability of the management to make sure that all diverse customer struggle is attended to be technicians with expert knowledge to resolve customers' problems.

\section{Conclusion}

This study emphasizes the research about customers' attitude towards Internet Banking services in Madurai city. The result of this research gave an outline of the attitude of customers and also they express their problems faced while using Internet banking. The study revealed a medium level of attitude towards Internet banking usage among bank customers. Most of the customers are facing low speed and connection loss while process problems while using internet banking. The banks should get feedbacks from the customers to rectify it. So every bank has to make a good perception of the Internet banking channel and encourage them to use Internet banking facilities. Banks have a vital role in promoting technology oriented banking channels to retain their valuable customers. 


\section{References}

Amin, Muslim. "Internet Banking Service Quality and Its Implication on e-Customer Satisfaction and e-Customer Loyalty." International Journal of Bank Marketing, vol. 34, no. 3, 2016, pp. 280-306.

Hammoud, Jamil. "The Impact of E-Banking Service Quality on Customer Satisfaction: Evidence From the Lebanese Banking Sector." Sage Open, vol. 8, no. 3, 2018.

Kapoor, B.N. E-Internet Banking, Alpha Books, 2009.

Kapoor, Nidhi. Computerized Banking System in India, Subline publications, 2008.

Manoranjan, Dash, et al. "Understanding Consumers' Risks Perception for Banking on the Internet." International Journal of Engineering and Management Sciences, vol. 3, no. 2, 2012, pp. 146-150.

Merugu, Pratima, and Krishna Mohan Vaddadi. "Customer Satisfaction towards Online Banking with Reference to Greater Visakhapatnam City." International Journal of Management, Technology and Engineering, vol. 8 , no. 12, 2018, pp. 3153-3165.

Muralidharan, D. Modern Banking: Theory and Practice, PHI Learning Private Limited, 2009.

Nayana. N., and K.P. Veena. "A Case Study on Employee Perception towards E-Banking." International Journal of Engineering Development and Research, vol. 6, no. 2, 2018, pp. 375-379.

"Online Banking." Wikipedia.

Parmar, Bhavesh J., et al. "Rural Banking through Internet: A Study on Use of Internet Banking among Rural Consumers." Asian Journal of Management Research, vol. 3, no. 2, 2013, pp. 325-335.

Ran, T. Santhiya, and A. Saravanan. "A Study on Customer Satisfaction towards Net Banking with Special Reference to General Banking customer in Coimbatore City." Journal of Emerging Technologies and Innovative Research, vol. 5, no. 11, 2018, pp. 134-138.

Reddy, D.N.V.K., and M. Sudhir Reddy. "A Study on Customer's Perception and Satisfaction towards Electronic Banking in Khammam District." IOSR Journal of Business and Management (IOSR-JBM), vol. 17, no. 12, 2015, pp. 20-27.

Samsunisa, A. "A Study on Customers' Perception towards Internet Banking Services at Chennai." Research Journal of Commerce and Behavioural Science, vol. 4, no. 12, 2015, pp. 72-78.

Sasidharan, K., and Alex K Mathews. Financial Service \& System, Tata Mcgraw-Hill, 2008.

Singhal, Divya, and V. Padhmanabhan. "A Study on Customer Perception towards Internet Banking: Identifying Major Contributing Factors." Journal of Nepalese Business Studies, vol. 5, no. 1, 2008, pp. 101-111.

Sunith, C.K. "Customer Satisfaction in E-Banking Services." International Journal of Business and Management Invention, vol. 8, no. 1, 2019, pp. 19-24.

Suriyamurthi, S., et al. "A Study on Customer Perception onwards Internet Banking." International Journal of Sales \& Marketing Management Research and Development (IJSMMRD), vol. 2, no. 3, 2012, pp.15-34.

Thomas, Abby. "A Study on Customer Perception towards Internet Banking." International Journal of Management Research and Social Science (IJMRSS), vol. 4, no. 1, 2017, pp.1719.

Uppal, R.K., and Rimpi Jatana. E-Banking in India: Challenges and Opportunities, New Century Publications, 2007.

\section{Author Details}

R. Andy, Assistant Professor (Research Scholar), Department of Commerce, Pasumpon Muthuramalinga Thevar College, Usilampatti, Madurai, Tamil Nadu, India.

Dr. A. Sujatha, Assistant Professor, Department of Commerce, Cardomon Plant Associations College, Bodinayakannur, Theni, Tamil Nadu, India. 